\title{
Outcome Analysis of Accreditacion Processes for Chilean Nursing Programs
}

\author{
Verónica Guerra Guerrero ${ }^{1}$ \\ Olivia Sanhueza Alvarado²
}

The National Undergraduate Accreditation Commission has been taking care of the accreditation process in several Nursing Schools, whose results are analyzed in this article, given the limited evidence of strengths and weaknesses. The objective is to analyze the first results obtained by that commission about the current development of Nursing in the country. The strengths obtained are: experience, qualification, commitment of teaching staff; welldefined study programs; adequate clinical training fields and infrastructure. Weaknesses are: reduced number of teachers; a curricular approach emphasizing biomedicine over nursing, low use of participative teaching methods; increasing difficulty to access exclusive clinical areas, and insufficient bibliographic resources. Conclusion: It is urgent that all Nursing Schools submit to universal criteria and standards, establishing minimum graduation levels for students, as well as the real state of the quality of nursing education in the country.

Descriptors: Education, Nursing; Schools, Nursing; Program Accreditation.

\footnotetext{
${ }^{1}$ RN. Doctoral Student in Nursing, Universidad de Concepción, Chile. Faculty, Escuela de Enfermería, Universidad Catolica del Maule, Chile. E-mail: vguerra@udec.cl.

${ }^{2}$ RN, Ph.D. in Nursing, Full Professor, Universidad de Concepción, Chile, e-mail: osanhue@udec.cl.
}

Corresponding Author:

Veronica Guerra Guerrero

Universidad Católica del Maule. Escuela de Enfermería

Avenida San Miguel no 3605

Talca, Chile

E-mail: vguerra@udec.cl 


\section{Análise dos resultados dos processos de acreditação do curso de enfermagem no chile}

A Comissão Nacional de Acreditacão da Graduação vem realizando processo de acreditação das Escolas de Enfermagem no Chile, cujos resultados são analisados neste artigo, dada à escassa evidência a respeito das fortalezas e debilidades das escolas avaliadas. O objetivo deste artigo é analisar os primeiros resultados obtidos por essa Comissão a respeito do desenvolvimento atual da enfermagem no país. Foram obtidos como fortalezas: experiência, qualificação, compromisso do corpo docente, plano de estudos definidos, infraestrutura e campos clínicos adequados. Como fraqueza obteve-se: reduzido número de docentes, modelo curricular biomédico sobrepondo-se ao modelo de disciplinas, baixa utilização de metodologias participativas de ensino, dificuldade crescente de acesso a campos clínicos exclusivos e bibliografia insuficiente. Conclui-se sobre a importância de todas as escolas de enfermagem se submeterem ao processo de acreditação, para que exista consenso sobre os níveis mínimos de qualidade, estabelecendo graus de qualificação na formação dos estudantes, como também para estabelecer a situação da profissão da enfermagem no país.

Descritores: Educação em Enfermagem; Escolas de Enfermagem; Acreditação de Programas.

\section{Análisis de resultados de los procesos de acreditación de la carrera de enfermería em Chile}

La Comisión Nacional de Acreditación de Pregrado chilena ha estado realizando la acreditación de las Escuelas de Enfermería, cuyos resultados son analizados en este artículo, dada la escasa evidencia respecto a las fortalezas y debilidades de las Escuelas evaluadas. El objetivo es analizar los primeros resultados obtenidos por esa Comisión respecto al desarrollo actual de la Enfermería en el país. Se obtuvieron como Fortalezas: experiencia, calificación, compromiso del cuerpo docente, plan de estudios definido, infraestructura, y campos clínicos adecuados. Y como Debilidades: reducido número de docentes, preponderancia curricular biomédica sobre los aspectos da las disciplinas, baja utilización de metodologías participativas de enseñanza, dificultad creciente de acceso a campos clínicos exclusivos, y, bibliografía insuficiente. Concluimos que es mandatorio que todas las Escuelas de Enfermería se sometan a criterios y estándares universales, para obtener un consenso sobre el nivel mínimo de formación para los estudiantes, como también establecer los estándares de calidad en la formación de enfermería en el país.

Descriptores: Educación en Enfermería; Escuelas de Enfermería; Acreditación de Programas.

\section{Introduction}

In the health sector, current demands determine the need for polyvalent professional education, directed towards a globalized view of commitment to health policies $^{(1)}$. Nursing education constitutes the essential base for the profession's development and progress ${ }^{(2)}$. To reach high-quality standards in education, curricular integration, teaching-care integration and competencybased curricular programs are essential in study plans $^{(1)}$. Achieving the presence of these elements ${ }^{(3)}$ in professional education demands their assessment through accreditation. The origins of higher education accreditation go back to $1847^{(4)}$. The first evaluation and accreditation systems of academic or curricular programs emerged in the United States and England, due to the pressure the industry exerted on universities, demanding high-quality graduates(5). It was only at 
the end of the $20^{\text {th }}$ century that it started to be used in Latin America(6), due to the range of higher education's coverage and diversification, changes in knowledge production forms and the demands of globalization(4). In Chile, accreditation started at the end of the 1990's and, specifically in Nursing programs, in 2003. Nowadays, evidence about the accreditation process of Nursing Colleges in Latin America is scarce, particularly in Chile. Considering the decisive moment Nursing is going through in that country, the following key questions should be answered: Until now, what have been the results of accreditation processes for Nursing Colleges that have been submitted to this legal standard? What benefits have been obtained? This can reveal, on the one hand, the current development phase of professional Nursing education and, on the other, define areas Nursing Colleges should concentrate their efforts in with a view to achieving the quality standards higher education has set and satisfying the population's health demands. This research aims to analyze the results of the accreditation processes Nursing Colleges at different Chilean universities have gone through. In the Chilean context, an additional goal is to contribute to existing knowledge about the state-of-the-art of higher Nursing education in Latin America, presenting its strengths and weaknesses as identified in the accreditation processes.

\section{Material and Method}

This systematic literature review was based on the Nursing accreditation reports; the original documentation, ranging from 2003 to 2007, was obtained from the CNA (National Accreditation Commission), in Chile. For data analysis, the accreditation criteria for nursing programs will be used, elaborated by the Technical Committee for Nursing in $2001^{(7)}$. To present the results, the same format as the CNA reports will be used, which include strengths and weaknesses. Nursing Colleges were divided according to the number of years they had been accredited, in function of their similarities in terms of strengths and weaknesses found.

\section{Reference Framework}

\section{Higher Education in Chile}

Higher education in Chile is offered at universities, professional institutes and technical training centers. Until 1980 , only eight universities existed in the country ${ }^{(8)}$. The political context and standards established to restructure higher education in that period, however, facilitated the increase to 40 universities at the end of the 1980 's ${ }^{(8)}$. Consequently, in 1990, the Higher Education Council $(\mathrm{HEC})^{(9)}$ was created to establish and administer an accreditation system for new universities and professional institutes. Later, in 1997, the Ministry of Education established the Program for the Quality Improvement and Equity of Higher Education (MECESUP), with a view to promoting the improvement of education in terms of quality and efficiency. Two commissions emerged from this program in 1999: The National Undergraduate Accreditation Committee (CNAP) and the National Graduate Accreditation Committee (CONAP)(3), which started the accreditation of university careers in Chile. In that county, accreditation is defined as formal and public recognition that an education program complies with the minimum graduate profile and with defined criteria and standards, which guarantee solid education in line with society's demands(7). The accreditation of undergraduate careers is based on previously set quality criteria( $^{(7)}$ and covers three procedures: Self-assessment of the respective program, External assessment by peers and CNAP Dictation. Accreditation terms range from a minimum of two years to a maximum of seven years $^{(7)}$. Quality criteria for Nursing include two spheres: the Professional Profile, which establishes the set of minimum competencies and skills any nursing program should address and its students should master when graduating from the program(7). It addresses both specific competencies and a set of general competencies. This aspect was not mentioned in the accreditation reports, which is why it will not be addressed in this research. The second sphere is that of assessment criteria themselves(7), including 10 titles, under which one general criterion and a range of specific criteria are established, which are: Goals of the Program, Institutional Integrity, Organizational and Administrative Structure, Professional Profile and Curricular Structure, Human Resources, Efficacy of teaching-learning process, Results of educative process, Infrastructure, Technical support and Resources for Teaching, Affiliation with context and Student Services and Well-being.

\section{Profile of higher nursing education}

The history of institutionalized Nursing education in Chile goes back to 1902, when the first Nursing course was held at the Hospital San Francisco de Borja. Soon afterwards, in 1906, the First Hospital Nursing College was created, which depended on the School of Medicine and Pharmacy at Universidad de Chile. Later, in 1947, 
the Second College was created in Southern Chile, at Universidad de Concepción and, in 1949 the third Nursing College at Pontificia Universidad Católica de Chile. In 1963, the Chilean Society of Nursing Education was set up(10), which would soon turn into the Chilean Association of Nursing Education (ACHIEEN)(11), aimed at safeguarding the quality of education. Nowadays, 34 Universities offer Nursing programs at 72 Nursing Schools, Departments or Institutes, from Arica to Punta Arenas, at public and private institutions. Some Chilean Nursing Colleges, both private and public, are grouped under the ACHIEEN, which is a scientific privately-held company, whose primary objective is to offer moral and material aid and support to the disadvantaged, especially in the areas of education and health, aimed at stimulating and coordinating the development of higher Nursing education in Chile $\mathrm{e}^{(11)}$.

\section{Results}

\section{General Description of Accreditation of Chilean Nursing Colleges}

Table 1 - Accreditation results of Nursing Schools, years $2003-2007$

\begin{tabular}{|c|c|c|c|c|c|}
\hline University & $\begin{array}{c}\text { Headquarters / Year of } \\
\text { creation }\end{array}$ & $\begin{array}{c}\text { No of Agreement and } \\
\text { Accreditation }\end{array}$ & $\begin{array}{l}\text { Total Years of } \\
\text { Accreditation }\end{array}$ & Date/Start & Date/End \\
\hline \multirow[t]{2}{*}{$\begin{array}{l}\text { U. Católica del Maule } \\
\text { (Public) }\end{array}$} & Talca 1992 & $\begin{array}{l}\text { First accreditation: } \\
\text { Agreement No } 32\end{array}$ & 3 years & 7 July 2003 & 7 July 2006 \\
\hline & & $\begin{array}{l}\text { Second accreditation: } \\
\text { Agreement No } 377\end{array}$ & 5 years & 9 January 2007 & 9 April 2012 \\
\hline $\begin{array}{l}\text { Pontificia U. Católica de } \\
\text { Chile (Public) }\end{array}$ & Santiago 1950 & Agreement No 114 & 6 years & 25 May 2004 & 25 October 2010 \\
\hline U. de Chile (Public) & Santiago 1906 & Agreement No 115 & 7 years & 20 July 2004 & 20 July 2011 \\
\hline U.de la Serena (Public) & Coquimbo 1993 & Agreement No 133 & 3 years & 16 November 2004 & 16 November 2007 \\
\hline U. de Concepción (Public) & Concepción 1948 & Agreement No 173 & 5 years & 19 April 2005 & 18 January 2010 \\
\hline U. de la Frontera (Public) & Temuco 1981 & Agreement No 293 & 4 years & 27 June 2006 & 27 June 2010 \\
\hline U. del Bío-Bío (Public) & Chillán 1971 & Agreement No 292 & 3 years & 27 June 2006 & 27 June 2009 \\
\hline U. Austral de Chile (Public) & Valdivia 1963 & Agreement No 295 & 5 years & 27 June 2006 & 27 June 2011 \\
\hline U. de Valparaíso. (Public) & Valparaíso 1933 San Felipe & Agreement No 294 & 3 years & $\begin{array}{l}3 \text { January } 2006 \\
27 \text { June } 2006^{*}\end{array}$ & 27 June 2009. \\
\hline U. de Tarapacá (Public) & Arica 1985 & Agreement No 305 & 2 years & 11 July 2006 & 11 October 2008 \\
\hline U. de Magallanes (Public) & Punta Arenas 1972 & Agreement No 316 & 2 years & 11 July 2006 & 11 October 2008 \\
\hline U. Andrés Bello (Private) & Santiago 2000 Viña del Mar & Agreement No 367 & 3 years & 9 January 2007 & 9 April 2010 \\
\hline U. Arturo Prat (Public) & Iquique 1997 Victoria & Agreement No 470 & 2 years & 26 June 2007 & 26 September 2009 \\
\hline U. de Antofagasta (Public) & Antofagasta 1981 & Agreement No 460 & 3 years & 26 June 2007 & 26 September 2010 \\
\hline
\end{tabular}

*The University of Valparaíso appealed to the result of the accreditation process in 2006 and was later accredited in June 2006. Source: National Accreditation Commission, (CNA. Chile), 2008.

Comments on Table 1.

About six years have passed since the start of accreditation. In this respect, until now, only 14 Nursing Colleges have been submitted to the accreditation process, which represents $19.4 \%$ of all institutions offering Nursing programs. Accreditation time ranges from two to seven years. When relating the years of accreditation with the years of existence, the oldest institutions have been awarded the longest accreditation period. The opposite is the case for more recent Colleges, which have only been accredited for two or three years. Only one College, representing $7.14 \%$ has achieved maximum accreditation time. Most universities have been accredited for three years, corresponding to $35.71 \%$. Three universities have been accredited for the minimum time, which is two years.

Main strengths and weaknesses in the accreditation of Nursing Schools in Chile 
Table 2 - Main strengths in Schools accredited for five years or more

\begin{tabular}{|c|c|}
\hline CNAP criteria & Strengths of academic units \\
\hline 1. Goals of program & $\begin{array}{l}\text { Clearly defined profile, incorporates institutional mission. Well-defined study plan. Unit goals } \\
\text { coherent with the institution. }\end{array}$ \\
\hline 2. Institutional integrity & Socialized mission, goals and objectives. Clear admission criteria. \\
\hline 3. Organizational and administrative structure & $\begin{array}{l}\text { Management staff with necessary background and experience. Structure permits adequate } \\
\text { program management. }\end{array}$ \\
\hline 4. Professional profile and structure & $\begin{array}{l}\text { Clearly defined profile. Partnership agreements with assistant faculty guarantee clinical training } \\
\text { areas. Good theoretical-practical integration Practice of pedagogical methods. }\end{array}$ \\
\hline 5. Human resources & $\begin{array}{l}\text { Teaching staff with necessary background and experience, qualified, high level of commitment } \\
\text { and motivation. Institutional interest in development of academic staff. Personal commitment of } \\
\text { support to the program. }\end{array}$ \\
\hline 6. Efficacy of teaching-learning process & $\begin{array}{l}\text { Follow-up of students' progress, correction strategies. Students and graduates' commitment } \\
\text { to the program. Qualified students in some programs only. Policies improve reproof and } \\
\text { graduation rates. }\end{array}$ \\
\hline 7. Results of education process. & $\begin{array}{l}\text { Updating of study plans according to disciplinary demands and demographic changes. Good } \\
\text { relation with graduates and employers. }\end{array}$ \\
\hline $\begin{array}{l}\text { 8. Teaching infrastructure, technical support and } \\
\text { resources }\end{array}$ & Adequate physical infrastructure, good laboratory equipment. Adequate text material. \\
\hline 9. Affiliation with context & $\begin{array}{l}\text { Bonds with national and international organizations. Narrow bonds with the job, class entity } \\
\text { and health context. Community service activities. }\end{array}$ \\
\hline 10. Student services and well-being & ------------ \\
\hline
\end{tabular}

Source: Results Analysis of Nursing Program Accreditation Processes in Chile. Guerra V. Sanhueza O. 2008.

Table 3 - Main strengths in Schools accredited for less than five years

\begin{tabular}{|c|c|}
\hline CNAP criteria & Strengths of academic units \\
\hline 1. Goals of program & $\begin{array}{l}\text { Clearly defined profile, incorporates institutional mission. Well-defined study plan. Unit goals coherent } \\
\text { with the institution. }\end{array}$ \\
\hline 2. Institutional integrity & Socialized mission, goals and objectives. Clear admission criteria. \\
\hline 3. Organizational and administrative structure & $\begin{array}{l}\text { Management staff with necessary background and experience. Structure permits adequate program } \\
\text { management. }\end{array}$ \\
\hline 4. Professional profile and structure & $\begin{array}{l}\text { Clearly defined profile. Partnership agreements with assistant faculty guarantee clinical training } \\
\text { areas. Good theoretical-practical integration Practice of pedagogical methods. }\end{array}$ \\
\hline 5. Human resources & $\begin{array}{l}\text { Teaching staff with necessary background and experience, qualified, high level of commitment and } \\
\text { motivation. Institutional interest in development of academic staff. Personal commitment of support to } \\
\text { the program. }\end{array}$ \\
\hline 6. Efficacy of teaching-learning process & $\begin{array}{l}\text { Follow-up of students' progress, correction strategies. Students and graduates' commitment to the } \\
\text { program. Qualified students in some programs only. Policies improve reproof and graduation rates. }\end{array}$ \\
\hline 7. Results of education process. & $\begin{array}{l}\text { Updating of study plans according to disciplinary demands and demographic changes. Good relation } \\
\text { with graduates and employers. }\end{array}$ \\
\hline $\begin{array}{l}\text { 8. Teaching infrastructure, technical support } \\
\text { and resources }\end{array}$ & Adequate physical infrastructure, good laboratory equipment. Adequate text material. \\
\hline 9. Affiliation with context & $\begin{array}{l}\text { Bonds with national and international organizations. Narrow bonds with the job, class entity and } \\
\text { health context. Community service activities. }\end{array}$ \\
\hline
\end{tabular}

Source: Results Analysis of Nursing Program Accreditation Processes in Chile. Guerra V. Sanhueza O. 2008. 


\section{Comments on Tables 2 and 3.}

When examining the mains strengths, common elements can be established that are generally repeated and do not depend on how long programs have been accredited. Thus, the following main strengths were found: existence of experienced teaching and management staff, highly qualified and committed to the program; commitment to the program is found among students as well; graduate profiles and study plan are clear and well-defined in most schools, address the subjects' perspective, are articulated with practice and use adequate teaching-learning methods; existence of infrastructure, support resources and clinical fields; existence of bonds with national and international institutions and with the nursing area, which need to be developed in punctual cases only; and existence of academic follow-up mechanisms, support and advisory strategies that favor students' progress in the study plan.

Table 4 - Mean weaknesses of Schools accredited for five years or more

\begin{tabular}{|c|c|}
\hline CNAP criteria & Weaknesses of academic units \\
\hline 1. Goals of program & Not well-defined graduate profile. Does not explicitly cover general and specific competencies. \\
\hline 2. Institutional integrity & -------------- \\
\hline $\begin{array}{l}\text { 3. Organizational and administrative } \\
\text { structure }\end{array}$ & ---------- \\
\hline 4. Professional profile and structure & $\begin{array}{l}\text { Partial learning assessment, impedes comprehensive assessment of study plan. Study plan does } \\
\text { not cover nursing contents. Excessive distance between theory and practice. Overloaded curriculum. } \\
\text { Inadequate student time organization, impedes extracurricular activities. }\end{array}$ \\
\hline 5. Human resources & $\begin{array}{l}\text { Inadequate faculty time organization, impedes extracurricular activities. Teaching load makes research } \\
\text { or community services more difficult. Lack of medium and long-term qualification plan. Rotation of } \\
\text { part-time faculty. Human resources adjusted to teaching, clinical practice and research. }\end{array}$ \\
\hline 6. Efficacy of teaching-learning process & Lack of established processes for graduate follow-up in some cases. \\
\hline 7. Results of education process. & $\begin{array}{l}\text { Lack of formal entities for participation by faculty from other units and clinical teachers. Partial learning } \\
\text { assessment impedes comprehensive valuation of study plan and makes knowledge integration more } \\
\text { difficult. Lack of student follow-up system. }\end{array}$ \\
\hline $\begin{array}{l}\text { 8. Teaching infrastructure, technical support } \\
\text { and resources }\end{array}$ & Insufficient infrastructure and equipment for number of students. Insufficient bibliographic resources. \\
\hline 9. Affiliation with context & $\begin{array}{l}\text { Incipient research in some cases, lack of clarity in research policies and lines. Informal and insufficient } \\
\text { relation with external context. Lack of permanent and fluid work plan with clinical areas outside the } \\
\text { health network. }\end{array}$ \\
\hline 10. Student services and well-being & 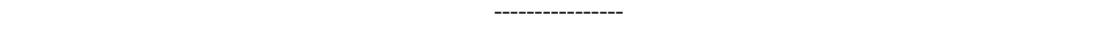 \\
\hline
\end{tabular}

Source: Results Analysis of Nursing Program Accreditation Processes in Chile. Guerra V. Sanhueza O. 2008.

Table 5 - Main weaknesses of Schools accredited for less than five years

\begin{tabular}{ll}
\hline \multicolumn{1}{c}{ CNAP criteria } & \\
\hline 1. Goals of program & Graduate profile lacks clarity in competency definition. Lack of dissemination of this profile among \\
& students and faculty. \\
2. Institutional integrity & No institutional policy is perceived that promoted the development of assessed units. Lack of \\
& dissemination of graduate profile among students, faculty in basic sciences and those responsible for \\
& clinical training. Special admission percentages exceed the number of students the program can attend. \\
3. Organizational and administrative & Organizational structure impairs the program's development. Lack of coordination levels for decision \\
structure & making in the management staff. \\
4. Professional profile and structure & Curriculum with a biomedical focus dominates the nursing focus. Lack of integration between basic and \\
& professional subjects. Overloaded and strict curriculum that makes it difficult to link theory and practices. \\
& In some cases, the course curriculum looks like graduate education. No clear methodological teaching- \\
& learning framework.
\end{tabular}


Table 5 - Continuation

\begin{tabular}{|c|c|}
\hline CNAP criteria & Weaknesses of academic units \\
\hline 5. Human resources & $\begin{array}{l}\text { Teaching staff limited in number and dedication time. Human resources submitted to high workloads. } \\
\text { Lack of academic human resource policy. Scarce bonding with students from other departments. No } \\
\text { mechanisms to assess the performance of faculty and authorities. }\end{array}$ \\
\hline $\begin{array}{l}\text { 6. Efficacy of teaching-learning } \\
\text { process }\end{array}$ & $\begin{array}{l}\text { High dropout rates and delayed graduation times. No analysis of students' progress. High reproof levels in } \\
\text { some basic science subjects. Hardly effective admission criteria in some cases. No formalized correction } \\
\text { support mechanisms. No clearly defined methodological framework. }\end{array}$ \\
\hline 7. Results of education process. & $\begin{array}{l}\text { Insufficient participation and decision-making mechanisms on academic themes, does not cover } \\
\text { participation by faculty hired per hour, faculty from other departments, students, graduates and } \\
\text { professionals. No analysis of students' progress with a view to identifying and putting in practice the } \\
\text { changes needed to improved education processes. }\end{array}$ \\
\hline $\begin{array}{l}\text { 8. Teaching infrastructure, technical } \\
\text { support and resources }\end{array}$ & $\begin{array}{l}\text { Insufficient bibliography and computer resources. In some cases, clinical training areas do not absorb all } \\
\text { students. }\end{array}$ \\
\hline 9. Affiliation with context & $\begin{array}{l}\text { Institutional goals do not include research and community service. No formal research promotion program. } \\
\text { Weak affiliation with the context. At some universities, evidence that existing national and international } \\
\text { bonds are not used to improve faculty and students. }\end{array}$ \\
\hline 10. Student services and well-being & 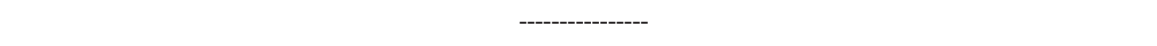 \\
\hline
\end{tabular}

Source: Results Analysis of Nursing Program Accreditation Processes in Chile. Guerra V. Sanhueza O. 2008.

Comments on Tables 4 and 5.

The main weaknesses found in the accreditation, shared by all accredited schools, are: a very tight number of human or teaching resources to develop teaching, clinical practice and research, highlighting their high workload and the impossibility of performing extracurricular activities, mainly related to research; an overloaded curriculum for the students; at some units, however, the curriculum still has a biomedical focus that is superimposed on nursing aspects; high reproof rates and absence of correction and follow-up mechanisms; difficulties in student plans in terms of competency definition, absence of teaching-learning methods, lack of sufficient clinical training areas and lack of bibliographical material.

\section{Discussion}

The years of accreditation indicate that some academic units are in better conditions to offer Nursing programs than others. All units should obtain the longest possible accreditation time. This may not be the most strategic result, as it could lead to a status quo, which is not convenient. Schools accredited for shorter periods are obliged to work on their weaknesses by adapting to current times ${ }^{(1)}$, especially with regards to methods, curriculum and study plans, leaving aside the biomedical and concentrating on the disciplinary model, based on competencies $^{(1)}$, infrastructure, human resources and research development. Units accredited for longer periods should maintain and improve the quality they presented, as that would allow for the competition needed to achieve the professional excellence the job market demands, which is the starting point of accreditation processes $^{(4)}$. With respect to the central theme of this analysis, criticism is based on the form and contents of accreditation reports. These would be expected to judge the two spheres covered by the criteria, but the minimum Professional Profile is ignored. On the one hand, the same order the CNAP established as assessment criteria (10 assessment titles) was expected ${ }^{(7)}$. The reports, however, refer to another reality. On the other hand, reports show mutual differences, as some titles are avoided or the established order is not preserved in their presentation focus. As for the contents, the reports do not allow for comparisons among different colleges, because information is omitted, which definitely exists and refers to each college's functioning, related to: students, social and care context and the internal reality of the same university. One could also think that, in each accreditation process, all assessment criteria were evaluated, but left out of the reports. In this sense, public reports should be requested to present the same assessment type, in terms of form as well as contents, with a defined and clear standard(5), as these reports are public and reviewed by different educational and social entities and spheres.

\section{Conclusions}

The elaboration of universal criteria and standards is essential, for local as well as international use in high- 
quality professional training, in accordance with the needs and demands of the globalized world. Accreditation is a tool that permits identifying strengths and weaknesses in higher education institutions. To the extent that these elements can be identified, potentiated and improved, educational quality can reach the goal accreditation aims for, that is: "To guarantee the quality of higher education". It is fundamental that educational and health entities focused on this area can review, assess, socialize and analyze the reports of these accreditations, and that this activity be actively developed. All Nursing Colleges should participate in accreditation, especially those affiliated with private universities, as these represent the largest part of higher education institutions offering nursing programs and concentrating a high number of students. In the future, mechanisms are due to promote and require that higher education institutions compulsorily submit to the accreditation process.

\section{References}

1. Silva KL, Sena RR. La Educación de Enfermería: Búsqueda de la Formación Crítica y Reflexiva y de las Competencias Profesionales. Rev Latino-am Enfermagem [Articulo Original Online] 2006 Septiembre-Octubre [Citado 2009 Marzo 13]; 14(5): Disponible en: URL:http://www.scielo.br/pdf/rlae/v14n5/es_ v14n5a18.pdf.

2. Arratia A. La Innovación en la Educación Superior en Enfermería y los aportes del diseño de instrucción. Rev Latinoam Enfermagem 1999 Abril; 7(2):5-13.

3. Mejoramiento de la calidad de la educación superior, MECESUP [Página principal en internet]. Aseguramiento de la Calidad. Acreditación [Citado 2008 Mayo 20]. Disponible en: http://www. mecesup.cl/info_mece2/sitio/index.php

4. Llanes C, Rivero O. Acreditación docente para obtener calidad en la educación de enfermería. Rev Cubana Enferm [Artículo Online] 2005 Enero-Abril [Citado 2009Marzo13];21(1):Disponible en: URL: http://bvs.sld.cu/revistas/enf/indice.html

5. Niño J, Herrera W. Tendencias en la Autoevaluación y Acreditación de Programas Curriculares e Instituciones. Rev Colombiana Física 2006; 38(1):197-200.

6. De Vries W. La acreditación mexicana desde una perspectiva comparativa. Revista Complutense Educ 2007; 18(2):11-28.
7. Comisión Nacional de Acreditación, CNA [Página principal en internet]. Sistema Nacional de Aseguramiento de la Calidad de la Educación Superior [Citado 2009 Julio 24]. Disponible en: http://www.cnachile.cl/docs/materiales/criteriosespecificos/ enfermeria.pdf

8. Consejo Superior de Educación [Página principal en internet]. Educación Superior en Chile.[Citado2008Septiembre1]. Disponibleen:http://www.cse.cl/public/Secciones/ seccioneducacionsuperior/educacion_superior_home.aspx

9. Biblioteca del Congreso Nacional [Página principal en internet]. Comisión Nacional de Acreditación. Ley Nº 18.962, Orgánica Constitucional de Enseñanza (LOCE.). 1990 Marzo. Artículo No 32. [Citado 2009 Abril 27]. Disponible en: http://www.bcn.cl/ leyes/pdf/actualizado/30330.pdf

10. Colegio de Enfermeras de Chile [Página principal en internet]. Reseña cronológica de la Enfermería en Chile. 19022006. [Citado 2008 Mayo 13]. Disponible en: http://www. colegiodeenfermeras.cl

11. Asociación Chilena de Educación en Enfermería [Página principal en internet]. Quiénes somos. Estatutos Asociación Chilena de Educación en Enfermería. [Citado 2008 Mayo 20]. Disponible en: http://www.achieen.cl/achieen/quienessomos.htm 